\title{
THE EFFECT OF DAIRY-SHED EFFLUENT IRRIGATION ON THE OCCURRENCE OF PLANT PATHOGENIC PYTHIUM SPECIES IN PASTURE
}

\author{
N.W. WAIPARA ${ }^{1}$ and S.K. HAWKINS ${ }^{2}$ \\ ${ }^{I}$ New Zealand Pastoral Agricultural Research Institute Ltd., \\ Ruakura Research Centre, Private Bag 3123, Hamilton, New Zealand \\ ${ }^{2}$ University of Waikato, Private Bag 3105, Hamilton, New Zealand
}

\begin{abstract}
A preliminary survey of pastures spray-irrigated with dairy-shed effluent revealed a significant increase in the population of plant pathogenic Pythium species isolated from both soil and roots. In vitro pathogenicity tests showed the majority of these isolates to be pathogenic when inoculated onto the seedlings of white clover, subterranean clover and perennial ryegrass, although both clover species were more susceptible to Pythium-induced disease than ryegrass.
\end{abstract}

Keywords: Pythium, soil, pasture, pathogenicity, dairy-shed effluent.

\section{INTRODUCTION}

The practice of using spray irrigation for disposal of dairy-shed effluent onto pasture is a growing trend in dairying regions of New Zealand. Effluent disposal applied to pastures can affect the microbial populations in soil, for example, di Menna $(1966 a, b)$ reported changes in soil yeast populations after irrigation with dairy factory effluents. Current local research into the effects of dairy-shed effluents on soil is investigating the inoculation of potentially harmful pathogenic bacteria and protozoa in soil. However effluent effects on resident soil microfungi including potentially phytopathogenic fungi have not been investigated.

Oomycetous fungi, such as Pythium, are economically important soilborne pasture plant pathogens (Chakraborty et al. 1996) causing seed rot, damping-off of establishing pasture seedlings and root rot diseases (Hawthorne 1988) of leguminous and graminaceous pasture plants. This affects the productivity and composition of pasture swards (Chakraborty et al. 1996). It has also been reported previously that the phytopathogenic oomycete genera Pythium and Phytophthora can be present in, and stimulated by, irrigation effluents (MacDonald et al. 1994). The effect of dairy-shed effluent amendments on phytopathogenic oomycete populations in pasture was investigated in a preliminary survey of a case study trial site in the Waikato.

\section{METHODS}

Soil core samples containing white clover plants were removed from a dairy farm where dairy-shed effluent was routinely applied to pasture. Soil was taken from pastures where effluent had been applied within the past seven days. Sampling was conducted over summer (January - March). Due to the pasture grazing rotation management on the farm over this period, effluent was applied to three soil types at various times: Puketaha soil (Jan/Feb), consolidated peat soil (Feb/Mar) and Horotui sandy loam (March only).

To provide control comparisons, soil cores were also removed from the same soils where dairy-shed effluent had never been applied to pasture. Each treatment was replicated three times. Soil and root samples were collected using a $5 \mathrm{~cm}$ soil corer to a depth of $10 \mathrm{~cm}$, samples were bulked together and initially sieved through a $1 \mathrm{~cm}$ sieve to separate soil, debris and roots. 


\section{Isolation from soil}

Two methods were used in parallel to selectively obtain oomycetous fungi from soils.

The first was a soil dilution plating method described by Martin (1992). Ten grams of each soil sample was suspended in $100 \mathrm{ml}$ sterile distilled water and shaken for 15 min. Serial dilutions of the soil suspensions $\left(10^{0}, 10^{-1}\right.$ and $\left.10^{-2}\right)$ were made and $0.1 \mathrm{ml}$ spread onto a selective medium, Modified Pimaricin Vancomycin with Minor elements (MPVM, Ali-Shtayeh et al. 1986). The second method was a simplified particle filtration procedure as outlined by Bills \& Polishook (1994). Soil samples were homogenised, washed and sieved to obtain samples of plant debris and soil particles $<125 \mu \mathrm{m}$ in size which were then plated onto MPVM plates. Each treatment of both methods was replicated three times.

\section{Isolation from roots}

White clover roots were removed from soil cores, washed in running tap water to remove soil, rinsed four times in sterile distilled water and dried on sterile filter paper. Root pieces were then cut to segments of $2-5 \mathrm{~mm}$ and plated onto MPVM, five segments per plate. A total of 100 root pieces from each treatment were plated.

The same procedure was also used to plate pieces of decomposing roots obtained by sieving soil samples. Fifty decomposing root pieces $(2-5 \mathrm{~mm})$ from each treatment were plated.

Fungi obtained from MPVM plates were subcultured onto potato carrot agar for identification. Preliminary identification of isolates was undertaken according to methods of Domsch et al. (1980).

\section{Pathogenicity screen}

A standard petri plate technique (Christensen et al. 1988) was used to assess the pathogenicity of Pythium spp to axenically grown seedlings of white clover (Trifolium repens L. cv. Grasslands Huia), subterranean clover (Trifolium subterranuem L. cv. Grasslands1003) and perennial ryegrass (Lolium perenne L. cv. Grasslands Nui). Seedlings were inoculated with $5 \mathrm{~mm}$ culture plugs of 52 Pythium isolates obtained from effluent-amended pastures and assessed after 10 days for disease symptoms using criteria outlined previously (Waipara et al. 1996a).

All data were analysed by analysis of variance using LSD tests for separation of means.

\section{Isolation of Pythium}

\section{RESULTS AND DISCUSSION}

A total of 78 Pythium isolates were recovered on MPVM plates (Table 1), with most being isolated from root pieces. This result was not unexpected as most species are primary or secondary attackers of plant root systems (Waterhouse 1973) and parasites of living plant tissues. To date four species have been identified: Pythium afertile (2 isolates), $P$. debaryanum (3 isolates), $P$. irregulare (11 isolates) and $P$. ultimum (7 isolates).

TABLE 1: Total number of Pythium isolated from effluent amended pastures from January to March 2000.

\begin{tabular}{lrrrrrrrr}
\hline & \multicolumn{9}{c}{ Month } & \\
\cline { 2 - 7 } & \multicolumn{2}{c}{ January } & \multicolumn{2}{c}{ February } & \multicolumn{2}{c}{ March } & Total \\
Effluent status & $(+)$ & $(-)$ & $(+)$ & $(-)$ & $(+)$ & $(-)$ & \\
\hline Roots & 18 & 4 & 19 & 7 & 3 & 0 & 51 \\
Soil & 5 & 6 & 1 & 0 & 12 & 3 & 27 \\
Sub totals & $23^{1}$ & 10 & $20^{1}$ & 7 & $15^{1}$ & 3 & 78 \\
Total & & 33 & & & 27 & & 18 & \\
\hline
\end{tabular}

${ }^{1}$ No. of Pythium significantly higher between $(+)$ and $(-)$ effluent treatment $(\mathrm{P}<0.05)$. 
The number of Pythium isolates recovered from effluent irrigated pastures was significantly higher $(\mathrm{P}<0.05)$ than unamended control pastures (Table 1$)$, clearly showing that dairy-shed effluent irrigation stimulated Pythium populations in pastures. A decline in the number of isolates obtained from roots was observed during the course of the summer (Table 1). However, the sub-total of Pythium numbers isolated from soil rose during this time, indicating propagules were still present despite the loss of their primary root substrates. Rainfall measured over the farm area surveyed also decreased over the sampling period (January $68 \mathrm{~mm}$, February $43 \mathrm{~mm}$ and March $31 \mathrm{~mm}$ ). The lower rainfall may have caused the drop in Pythium isolations from roots in February and March, since higher soil moisture promotes root infection, sporulation and growth of this genus (Ingold and Hudson 1993).

The total number of Pythium isolates obtained from Puketaha pastoral soil was higher (Table 2) than both consolidated peat or Horotui sandy loam soils, however the latter was only sampled once and the difference in isolation frequency between treatments was not significant. Effluent irrigation significantly increased Pythium numbers in both Puketaha and consolidated peat soils (Table 2).

TABLE 2: Total number of Pythium isolated from soil from January to March 2000.

\begin{tabular}{|c|c|c|c|c|c|c|c|}
\hline Effluent status & \multicolumn{2}{|c|}{ Puketaha soil } & \multicolumn{2}{|c|}{$\begin{array}{c}\text { Consolidated Peat } \\
(+)\end{array}$} & \multicolumn{2}{|c|}{$\begin{array}{l}\text { Horotui sandy loam } \\
\qquad(+)\end{array}$} & Total \\
\hline Roots & 25 & 5 & 12 & 6 & 3 & 0 & 51 \\
\hline Soil & 5 & 6 & 10 & 2 & 3 & 1 & 27 \\
\hline \multirow[t]{2}{*}{ Total } & $30^{1}$ & 11 & $22^{1}$ & 8 & 6 & 1 & 78 \\
\hline & \multicolumn{2}{|c|}{41} & \multicolumn{2}{|c|}{30} & \multicolumn{2}{|c|}{7} & \\
\hline
\end{tabular}

${ }^{1}$ No. of Pythium significantly higher between $(+)$ and $(-)$ effluent treatment $(\mathrm{P}<0.05)$.

Although Pythium was the dominant genus of fungi isolated in this case study, isolates of another Oomycete genus, Phytophthora, were obtained from clover roots. In addition, isolates from related Zygomycete genera Mortierella, Gongronella and Absidia were also recovered from all treatments.

\section{Pathogenicity of Pythium spp.}

Approximately $80 \%$ of the 52 isolates of Pythium tested against white clover, perennial ryegrass and subterranean clover seedlings were pathogenic, ranging from being mildly pathogenic (inhibition of root growth and disease lesioning of roots) to highly pathogenic (shoot and root rot and necrosis/damping off) (Fig. 1). Ryegrass

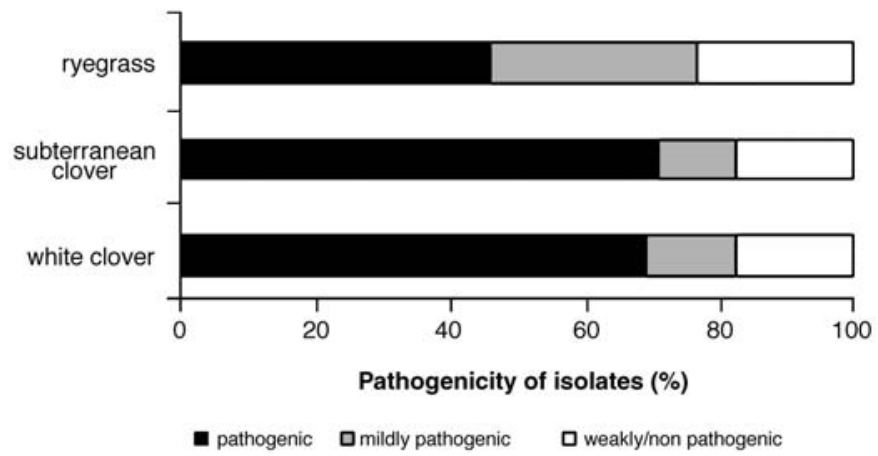

FIGURE 1: Percentage pathogenic Pythium isolates recovered from effluent irrigated pastures. 


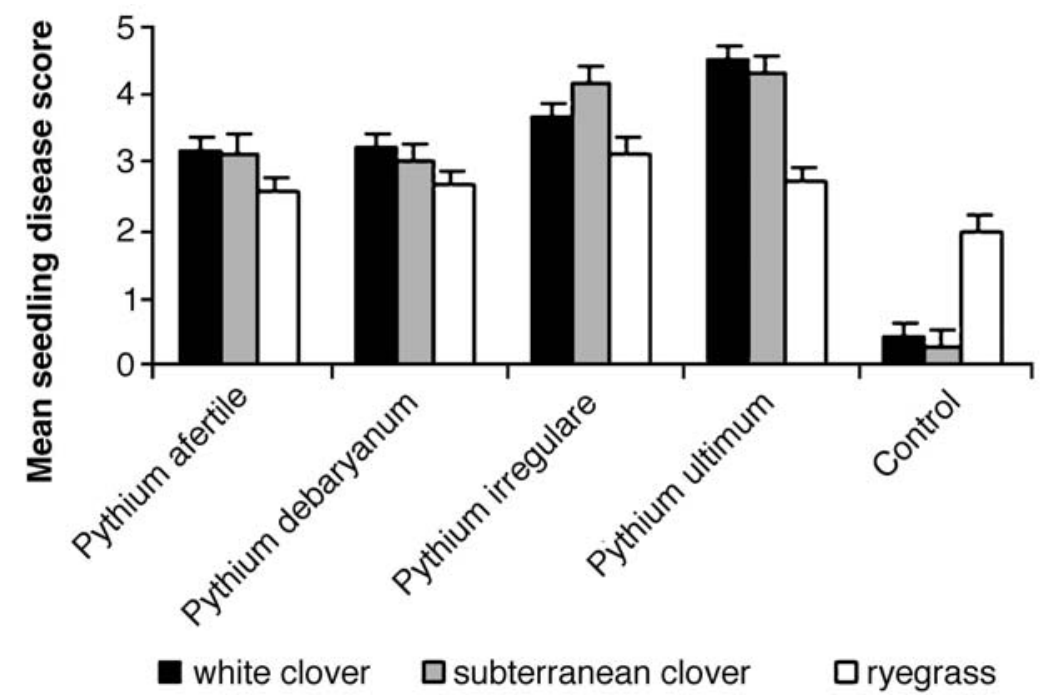

\section{FIGURE 2: Pathogenicity of four Pythium species to pasture seedlings. Error bars represent LSD at $\mathrm{P}<0.05$.}

seedlings were less susceptible to disease than clover as slightly more Pythium isolates were non-pathogenic and a lower number of pathogenic isolates were also observed. A higher susceptibility of pasture legumes to fungal root diseases, compared to pasture grasses, has been frequently observed (Waipara et al. 1996a,b).

All seedlings inoculated with Pythium had more $(\mathrm{P}<0.05)$ root rot symptoms than the uninoculated controls (Fig. 2). The four species of Pythium differed in pathogenicity to the three hosts tested (Fig. 2) with $P$. ultimum and $P$. irregulare most pathogenic, particularly to both clover hosts, where significantly $(\mathrm{P}<0.05)$ more disease symptoms were observed. Root disease symptoms (root lesions and root browning) were observed on all inoculated ryegrass seedlings, which indicated a similar susceptibility to all four Pythium species.

Although an increase of pathogenic Pythium populations in soils could affect pasture establishment, productivity and sward composition (Chakraborty et al. 1996), other soil micro-organisms, such as beneficial competitive Trichoderma saprophytes and mycoparasites, may also be stimulated in effluent amended soils. This could limit the overall impact of pathogenic Pythium species. For example, long-term irrigation was reported to stimulate Trichoderma in pastoral soils (Ruscoe 1973). Other beneficial effects from effluent irrigation, such as increased nitrogen levels stimulating pasture growth, may also counter any losses to plant growth caused by pythiaceous pathogens. It is unclear whether the irrigation water with effluent, the effluent solids or both lead to the increase in Pythium numbers.

\section{CONCLUSIONS}

The application of dairy-shed effluent to pasture was found to increase the number of plant pathogenic Pythium strains isolated from roots and soil. Although pathogenicity varied between Pythium species, and isolates of species, more pathogenic than nonpathogenic strains were found to be present. Further investigation is needed to elucidate Pythium populations in pastoral soil ecosystems and how dairy-shed effluent irrigation affects overall microbial biodiversity in soil, in particular the economically significant deleterious plant pathogens. 


\section{ACKNOWLEDGMENTS}

We thank Gabriela Burch for collection of samples and use of her farm as trial site, Dr Upali Sarathchandra and Dr Margaret di Menna for sampling and methodology advice, Wilma Mathieson for technical assistance and Dr Neil Cox for statistical analyses.

\section{REFERENCES}

Ali-Shtayeh, M.S., Len, L.H.C. and Dick, M.W., 1986. An improved method and medium for quantitative estimates of populations of Pythium species from soil. Trans. Br. Mycol. Soc. 86: 39-47.

Bills, G. F. and Polishook, J.D., 1994. Abundance and diversity of microfungi in leaf litter of a lowland rain forest in Costa Rica. Mycologia 86:187 - 198.

Chakraborty, S., Leath, K.T., Skipp, R.A., Pederson, G.A., Bray, R.A., Latch, C.M. and Nutter, F.W., 1996. Pasture and Forage Crop Pathology. ASA, Madison, USA. 653 pp.

Christensen, M.J., Falloon, R.E., Skipp, R.A., 1988. A petri plate technique for testing pathogenicity to seedlings and inducing sporulation.Australasian Plant Path. 17: 45-47

di Menna, M.E., 1966a. Yeasts in soils spray irrigated with dairy factory wastes. N.Z. J. Ag. Res. 9: $576-589$.

di Menna, M.E., 1966b. Lipomyces in some New Zealand and Pacific soils. N.Z. J. Bot. 4: $406-417$.

Domsch, K.H., Gams, W. and Anderson, T-H., 1980. Compendium of Soil Fungi. Academic Press, New York, USA. 859 pp.

Hawthorne, B.T., 1988. Pathogenicity of Pythium spp. to lucerne seedlings and relationships between seed weight, seedling vigour, and infection by Pythium. N.Z. J. Ag. Res. 31: $359-364$.

Ingold, C.T. and Hudson, H.J., 1993. The Biology of Fungi. 6th Edition. Chapman \& Hall, London, UK.

MacDonald, J.D., Ali-Shtayeh, M.S., Kabashima, J. and Stites, J., 1994. Occurrence of Phytophthora species in recirculated nursery irrigation effluents. Plant Dis. 78:607-611.

Martin, F.N., 1992. Pythium. Pp 39 - 49 In: Methods for Research on Soilborne Phytopathogenic Fungi, L.L. Singleton, J.D. Mihail and C.M. Rush (Eds); APS Press, St Paul, USA.

Ruscoe, Q.W., 1973. Changes in the mycofloras of pasture soils after long-term irrigation. N.Z. J. Sci. 16: 9-20.

Waipara, N. W., di Menna, M. E., Cole, A. L. J. and Skipp, R. A., 1996a. Potential pathogenicity of pasture plant root-colonising fungi to seedlings of legumes and grasses. Proc. 49th N.Z. Plant Prot. Conf. :215-215.

Waipara, N. W., di Menna, M. E., Cole, A. L. J. and Skipp, R. A., 1996b. Pathogenicity of Cylindrocladium scoparium to pasture clover and grass species. Australasian Plant Path. 25: 205-211.

Waterhouse, G.M., 1973. Peronosporales. Pp 165-183 In: The Fungi; an advanced treatise, G.C. Ainsworth, F. Sparrow and A. Sussman (Eds); Academic Press Inc, New York, USA. 